Erythromelalgia due to calcium antagonists may be more frequent than reported. It is probably often reported as flushing or paraesthesia of the hands and feet. Doctors prescribing these drugs should be aware of this inverse Raynaud's phenomenon and withdraw the $\operatorname{drug}(\mathrm{s})$ before sending their patients for extensive investigations.

1 Kahan A, Amor B, Menkes CJ. Nifedipine and allied substances in the treatment of Raynaud's phenomenon. Adv Microcirc 1985;12:95-104.

2 Juergens JL, Spittel JA Jr, Fairbairn JR, eds. Peripheral vascular disease. 5th ed. Philadelphia: WB Saunders, 1980:601-5.

3 Fisher JR, Padnick MB, Olstein S. Nifedipine and erythromelalgia. Ann Intern Med 1983;98:671-2.

4 Brodmerkel GJ. Nifedipine and erythromelalgia. Ann Intern Med 1983;99:415.

5 Grunwald Z. Painful edema, erythematous rash, and burning sensation due to nifedipine. Drug Intell Clin Pharm 1982; 16:492.

6 Dupont E, Illum F, Olivarius B. Bromocriptine and erythromelalgia-like eruption. Neurology 1983;33:670

7 Baudouin-Legros M, Dard B, Guicheney P, Meyer P. Double action of nicardipine on serotonin release from rat platelets. $\mathcal{F}$ Cardiovasc Pharmacol 1987;10:287-91.

8 Mehta JL. Influence of calcium-channel blockers on platelet function and arachidonic acid metabolism. Am $f$ Cardiol 1985;55:158-64B.

9 Moore N, Biour M, Paux G, et al. Adverse drug reaction monitoring: doing it the French way. Lancet 1985;ii:1056-8.

\section{Tamoxifen-warfarin interaction: the Aberdeen hospitals drug file}

Drs Lewis D Ritchie and Sandra M T Grant (Medicines Evaluation and Monitoring Group, Aberdeen Royal Infirmary, Aberdeen AB9 2ZB) write: In Aberdeen for the past 17 years a computerised file of the drug history of each patient during hospital admission has been maintained.' The drug information is linked to personal and morbidity data, routinely collected for the Scottish Morbidity Return (SMR1). At the end of 1988 the file contained 932000 admissions with over 2.5 million drug prescriptions.

Following the report by Dr P Tenni and others on life threatening interactions between tamoxifen and warfarin, ${ }^{2}$ we examined all admissions to the Aberdeen general hospitals from 1980 to 1988 in which the two drugs had been prescribed together. Twenty nine such patients were identified and their case notes scrutinised. Seven were excluded (initial treatment elsewhere, or the two drugs were not given concurrently). In the remaining 22 cases no problems had been noted in 17 . In the five other cases two patients had grossly raised British comparative ratios on introduction of warfarin but no episode of bleeding; one had no noted problem with control but experienced a subconjunctival haemorrhage; one had difficulty with control and developed a haematoma of the thigh; and one, who was taking long term warfarin, had problems with intraocular haemorrhage and haemorrhagic rashes after tamoxifen was introduced. Our findings confirm those of Dr Tenni and colleagues and we echo their concerns about this life threatening interaction.

The Aberdeen hospitals drug file offers the opportunity for studying potential drug interactions. We would welcome further inquiries about specific uses for this facility.

1 Moir DC, Alexander ER, Barnett JW, Christopher LJ. A hospital based information system. Health Bulletin (Edinb) 1975;33:82-8.

2 Tenni $P$, Lalich DL, Byrne MJ. Life threatening interaction between tamoxifen and warfarin. Br Med $\mathcal{J}$ 1989;298:93. (14 January.)

Reversal of chloral hydrate overdose with flumazenil

Drs K L Donovan and D J Fisher (Cardiff Royal Infirmary, Cardiff CF2 1SZ) write: Dr J G Whitwam says that flumazenil has been used in many conditions other than to reverse sedation induced by benzodiazepines. ${ }^{\prime}$ We observed an interesting interaction between flumazenil and chloral hydrate taken in overdose.

A young man with a history of drug overdose was brought to the casualty department unconscious with respiratory depression and hypotension. Both pupils were constricted and his breath smelt sweet. Intravenous naloxone $(0.4 \mathrm{mg} \times 4$ doses $)$ produced no improvement, but flumazenil $200 \mu \mathrm{g}$, followed at one minute intervals by three further $100 \mu \mathrm{g}$ doses, produced a dramatic response with increased level of consciousness, verbalisation, and pupillary dilatation; both respiratory rate and blood pressure returned to normal. The sludge obtained by gastric lavage was shown to be chloral hydrate and he later admitted to having taken a total of $10 \mathrm{~g}$ of the drug in isolation.

Although flumazenil is a specific competitive benzodiazepine receptor antagonist, it has been shown to have a dramatic but inconsistent effect in ethanol intoxication, ${ }^{2-4}$ possibly by modifying the response of the $\gamma$ aminobutyric acid-benzodiazepine ionophore receptor complex to the effects of ethanol. ${ }^{5}$ The sedative mode of action of chloral hydrate, similar to that seen with benzodiazepines and ethanol, is poorly understood. The rapid reversal of recognised effects of chloral hydrate overdose seen in this case may therefore provide further information about the modes of action of both flumazenil and chloral hydrate. So far as we and the manufacturers are aware this has not been reported before, though attempted reversal of benzodiazepine-chloral hydrate induced sedation with flumazenil precipitated ventricular arrhythmias. ${ }^{6}$ The mechanism is unclear, but it may be that while flumazenil antagonised the benzodiazepine element it failed to protect against chloral hydrate arrythmogenesis, a well recognised side effect.

Whitwam JG. Flumazenil: a benzodiazepine antagonist. BrMed f 1988;297:999.

2 Lavizzari GS, Mathis H. Benzodiazepine antagonist (RO 15-1788) in ethanol intoxication: a pilot study. Eur Neurol 15-1788) in ethan
$1985 ; 24: 352-4$

3 Flotz U, Ziegler G, Rosonkrantz B, Mikus G. Does the benzodiazepine antagonist RO 15-1788 antagonise the action of ethanol? Br f Clin Pharmacol 1986;22:513-20.

4 Fluckiger A, Hartmann D, Leishman B, Ziegler WH. Lack of effect of the benzodiazepine antagonist flumazenil (RO 15-1788) on the performance of healthy subjects during experimentally induced ethanol intoxication. Eur $\mathcal{J}$ Clin Pharmacol 1988;34:273-6.

Costa E, Corda MG, Epstein B, Forchetti C, Guidotti A. GABA benzodiazepine interactions. In: Costa $\mathrm{E}$, ed. The benzodiazepine: from molecular biology to clinical practice. New York: Raven Press, 1983

6 Short TG, Maling T, Galletly DC. Ventricular arrhythmia precipitated by flumazenil. Br Med f 1988;296:1070-1.

\section{Cross sensitivity to antithyroid drugs}

Drs A SMITH, R F GLEDHILL, and P JENKINS (East Surrey Hospital, Redhill, Surrey RH1 5RH) write: Medical practitioners have come to rely on the British National Formulary for sound prescribing advice. The section on antithyroid drugs states, "Propylthiouracil may be used in patients who suffer sensitivity reactions to carbimazole as sensitivity is rarely displayed to both drugs." This statement runs counter to views expressed elsewhere, ${ }^{2-5}$ a standpoint which we highlight through the following case report.

A 66 year old woman presented to the accident and emergency department in June 1988 with a 24 hour history of pain in the wrists, elbows, shoulders, and interscapular area. Four months earlier she had had a myocardial infarction complicated by cardiac arrest and consequent thoracic spinal cord infarction. A flaccid, hyporeflexic paraplegia with diminution of pain sensation distal to either ankle had remained. She had been readmitted three months later in left ventricular failure with atrial fibrillation. At that time the serum free thyroxine concentration was $37 \mathrm{pmol} / \mathrm{l}$ normal $10 \cdot 4-24 \cdot 2$ ) and the thyroid stimulating hormone value $0 \cdot 16 \mathrm{mU} / 1(0 \cdot 44-3 \cdot 16)$. Carbimazole $15 \mathrm{mg}$ three times daily had been started on 23 May. This had been replaced on 13 June by propylthiouracil $100 \mathrm{mg}$ three times daily after the appearance (one week earlier) of a pruritic macular eruption. Daily concurrent medication comprised nifedipine $(60 \mathrm{mg})$, digoxin $(250 \mu \mathrm{g})$, and amiloride hydrochloride $5 \mathrm{mg}$ plus frusemide $40 \mathrm{mg}$ (Frumil; 2 tablets).

On admission her temperature was $38.4^{\circ} \mathrm{C}$ and pulse 84 beats/min with a regular rhythm. The rash had disappeared. Both arms were held immobile and in a disordered posture, the slightest displacement evoking an anguished response. No joint swelling or erythema was evident. A full blood count and standard biochemical profile gave normal results. The erythrocyte sedimentation rate (Westergren) was $30 \mathrm{~mm}$ in the first hour Tests for rheumatoid factor and antinuclear antibody gave negative results. The antibody titre to thyroglobulin was $1 / 1700$ and to thyroid microsomes 1/110000. Propylthiouracil was withdrawn on 17 June and dispersible aspirin $600 \mathrm{mg}$ four times daily given. The temperature settled and less opioid analgesic was required for pain relief. Two days later the patient suffered a fatal cardiac arrest.

Arthralgia without joint inflammation was the second most common side effect in a recent survey of 500 patients with thyrotoxicosis given antithyroid drugs. ${ }^{6}$ Of the five patients affected, four displayed sensitivity also to the alternative agent. Such events are not limited to rheumatic symptoms, cross sensitivity having been described in agranulocytosis, ${ }^{78}$ marrow aplasia, ${ }^{9}$ and hepatic injury. ${ }^{10}$ The reaction to a second agent may also be more severe than that to the first. ${ }^{79}$ Extensive immunological cross reactivity to all three antithyroid drugs was shown in patients who had developed agranulocytosis during treatment with either propylthiouracil or carbimazole. ${ }^{5}$ The thioamide group, common to each compound, may either have been the antigen or have become antigenic by forming a complex with a neutrophil protein. Cross sensitivity might also arise on the basis of close chemical analogy.

Our patient's rheumatic symptoms developed 24 hours after both the introduction of propylthiouracil and the withdrawal of carbimazole. Although the carbimazole rash had already resolved, this drug, rather than propylthiouracil, might have been responsible. At all events, some authors, having regard to the potential for cross sensitivity, advocate using alternate treatments for patients who manifest an adverse reaction to one antithyroid drug and who need further treatment for hyperthyroidism..$^{23}$ The prudence of this policy merits an amendment to the British National Formulary.

1 Joint Formulary Committee British national formulary. Number 16. London: British Medical Association and Royal Pharmaceutical Society of Great Britain, 1988:242.

2 Farbman K, Wheeler MF, Glick SM. Arthritis induced by antithyroid medication. NY State f Med 1969;69:826-31.

3 Hung W, August GP. A "collagen-like" syndrome associated with antithyroid therapy. $\mathcal{F}$ Pediatr 1973;82:852-4.

4 Cooper DS. Antithryoid drugs. $N$ Engl $\mathcal{F}$ Med 1984;311: 1353-62.

5 Wall JR, Fang SL, Kuroki T, Ingbar SH, Braverman LE. In vitro immunoreactivity to propylthiouracil, methimazole and carbimazole in patients with Graves' disease: a possible cause of antithyroid drug induced agranulocytosis. 7 Clin Endocrinol 1984;58:868-72.

6 Shabtai R, Shapiro MS, Orenstein D, Taragan R, Shenkman L. The antithyroid arthritis syndrome reviewed. Arthritis Rheum 1988;47:340-3.

7 Fraser TR, Garrod O, Hanno MGW, Jadresic A. Antithyroid activity and toxicity of mercazole and neo-mercazole. $f \mathrm{Clin}$ Endocrinol 1954:14:1230-44.

8 Chen B, Lang R, Jutrin Y, Ravid M. Recurrent agranulocytosis induced by two different antithryoid agents. Med $\mathcal{J}$ Aus 1983;ii:38-9.

9 Burrell CD. Fatal marrow aplasia after treatment with carbimazole. BrMed F 1956;i: 1456-7.

10 Martinez-Lopez JI, Greenberg SE, Kling RR. Drug-induced hepatic injury during methimazole therapy. Gastroenterology 1962;43:84-7. 